\title{
Ophiomusium acuferum (Ophiolepididae) and Ophiomisidium pulchellum (Ophiuridae) (Ophiuroidea: Echinodermata), redescription based on the Brazilian specimens
}

\author{
Michela Borges ${ }^{1} \&$ Lucia de Siqueira Campos ${ }^{2}$
}

\author{
${ }^{1}$ Museu de Zoologia, Instituto de Biologia, Universidade Estadual de Campinas. Rua Albert Einstein, Caixa Postal 6109, \\ 13083-863 Campinas, SP, Brazil. E-mail: borgesm@unicamp.br \\ ${ }^{2}$ Departamento de Zoologia, Instituto de Biologia, Universidade Federal do Rio de Janeiro. Avenida Carlos Chagas Filho 373 , \\ 21941-902 Rio de Janeiro, RJ, Brazil. E-mail: campos-lucia@biologia.ufrj.br
}

\begin{abstract}
Ophiomusium (Ophiolepididae) and Ophiomisidium (Ophiuridae) are similar, but differ in features such as size of the adult, number of disc dorsal plates, length of the arms, shape of the first ventral arm plates and number of the tentacle. In this contribution, a large number of specimens of Ophiomusium acuferum Lyman, 1869 and Ophiomisidium pulchellum (Wyville Thomson, 1878) were sampled from southeastern and southern Brazilian at depths ranging from 46 to $1300 \mathrm{~m}$. A close analysis has shown that specimens identified as Ophiomisidium pulchellum (C.W. Thomson, 1877 ) in several Brazilian museums are actually Ophiomusium acuferum Lyman, 1875. A total of 2330 individuals were examined: 2046 specimens of Ophiomusium acuferum ('Evaluation of the sustainable potential of living resources from the Brazilian Economic Exclusive Zone/Score South - Benthos' - REVIZEE; 'Rational usage of coastal ecosystems from the Brazilian Tropical Region: São Paulo State - Integrated Project/Subproject Benthos' - INTEGRADO; and the MD55/ Brazil) and 284 of Ophiomisidium pulchellum (MD55/Brazil). The disc diameter of each individual was measured and the specimens were digitally photographed. The samples studied are deposited in the Museum of Zoology of the University of Campinas and Institute of Biology at the Federal University of Rio de Janeiro. The specimens from the MD55 are deposited at the Paris Museum National d'Histoire Naturelle. An identification key to these species is provided here. A detailed morphological analysis and redescription of both species, comparisons, and their geographic distribution in Brazil are discussed.
\end{abstract}

KEY WORDS. Deep sea; morphology; ophiuroids; taxonomy.

Ophiomusium Lyman, 1869 (Ophiolepididae) and Ophiomisidium Koehler, 1914 (Ophiuridae) have similar diagnostic features. The latter was first described by KoEHLER (1914) for two species previously included in Ophiomusium. Ophiomisidium pulchellum (Wyville Thomson, 1878) and Ophiomisidium flabellum (Lyman, 1878). The two genera differ considerably in characteristics such as size of the adults, number of disc dorsal plates, length of the arms, shape of the first ventral arm plates and number of tentacle pores. For instance, species of Ophiomusium are generally larger than species of Ophiomisidium. By contrast, representatives of Ophiomisidium are small. Furthermore, they have few disc dorsal plates, extremely reduced ventral disc interradial space, reduced or absent bursal slits, and the first three ventral arm plates well developed (rudimental in Ophiomusium). Ophiomusium, as proposed by Lyman (1869), has strongly joint oral papillae, disc covered by plates and scales intimately welded, small dorsal and ventral arm plates, large lateral arm plates that are united dorsally and ventrally, and tentacle pores present only in the first basal segments of the arms.
Ophiomisidium pulchellum was first recorded off Pernambuco (Brazil) at $270 \mathrm{~m}$. It has been further recorded for Brazilian waters by TOMMAsI (1970) and Borges et al. $(2002,2004)$.

The objective of this paper is to discuss the differences between Ophiomusium acuferum Lyman, 1875 and Ophiomisidium pulchellum (C.W. Thomson, 1877) taking into account that both species have been confounded in more recent identifications. Also, a more detailed taxonomic account of O. acuferum is provided here in order to clarify its records for Brazil.

\section{MATERIAL AND METHODS}

A total of 2,330 individuals were examined using a stereomicroscope, 2,046 specimens of O. acuferum and 284 of $O$. pulchellum.

The studied ophiuroid specimens of O. acuferum Lyman, 1875 were sampled off the southwestern Atlantic, Brazilian Southeast region at different depth ranges by the following scientific programmes: 1) 'Evaluation of the sustainable potential of liv- 
ing resources from the Brazilian Economic Exclusive Zone/Score South - Benthos' (REVIZEE), from 120 to $380 \mathrm{~m}$ using a van Veen grab and rectangular dredge (Amaral et al. 2004); 2) 'Rational usage of coastal ecosystems from the Brazilian Tropical Region: state of São Paulo - Integrated Project/Subproject Benthos' (INTEGRADO), from 46 to $320 \mathrm{~m}$ using rectangular dredges (PIRESVanin 1993); and 3) the MD55/Brazil, from 200 to $315 \mathrm{~m}$ using different types of dredges (Gullle \& Ramos 1987, Tavares 1999). Most of these specimens had been previously mentioned as $O$. pulchellum in several papers (Borges et al. 2002, 2004).

Several specimens of the $O$. pulchellum were sampled by the MD55/Brazil from 825 to $1200 \mathrm{~m}$ using a Charcot Pickard Dredge (DC), a Chalut Blake (BC), a Chalut a Perche (CP) and/ or a Sanders Dredge (DS). A more recent deep-sea expedition undertaken through the 'Campos Basin Deep Sea Environmental Project/PETROBRAS' has provided additional material of this species from 1100 to $1300 \mathrm{~m}$ using a semi-balloon otter trawl.

Samples from the REVIZEE and Integrado were fixed in $6 \%$ seawater formalin and subsequently stored in $70 \%$ alcohol. All samples from the MD55 and the Campos Basin were fixed and preserved in alcohol.

The disc diameter of each individual was measured using a digital Mitutoyo CD-6 CS calliper. Specimens were digitally photographed with a video camera ZEISS, TK 1270U attached to the stereomicroscope. Most studied samples (2009 specimens) are deposited in the Museum of Zoology of the University of Campinas being identified by the abbreviation ZUEC-OPH (number in examined material). A total of 68 individuals (all O. pulchellum) are deposited at the Institute of Biology at the Federal University of Rio de Janeiro being identified by the abbreviation DZ/IB/UFRJ-EO (code number). The specimens from the MD55 have been deposited at the Paris Museum National d'Histoire Naturelle (MNHN IE 2007 - code number) and examined by the authors. These are 37 specimens of $O$. acuferum and 216 of $O$. pulchellum.

\section{TAXONOMY}

The identification key bellow differentiates species of Ophiomusium and Ophiomisidium occurring in Brazil.

\section{Key to the species of Ophiomusium and Ophiomisidium occurring in Brazil}

1. Adults reaching up to $15 \mathrm{~mm}$ in disc diameter (dd); disc covered dorsally with many relatively small, closely fused plates; two tentacle pores; arm with similar thickness along its entire length (Ophiomusium) 2

$1^{\prime}$. Adults smaller, up to $5 \mathrm{~mm}$ in dd; disc covered dorsally with few, relatively large plates in addition to the central rosette; number of tentacle pores varying, generally more than two; basal arm segments wider than posterior segments, giving the animal (disc + arms) the appearance of a star..... (Ophiomisidium)
2. Dorsal surface of disc covered with relatively small plates, with 10-12 plates between center and edge of disc; centrodorsal and primary scales not obvious; initially two small appressed arm spines, ventral spine larger; subsequently, three spines. Tip of arm with lower spine toothed and hook-shaped .....

Ophiomusium eburneum

$2 '$. Dorsal surface of disc covered with few, relatively large plates, with 4-6 plates between center and edge of disc; centrodorsal and primary scales obvious; three arm spines, at least on basal segments

.. 3

3. Basal arm segments with three elongated spines, of which upper spine is situated more dorsally, separated from the others; posterior segments with two spines

Ophiomusium acuferum

3'. Three small appressed arm spines on all arm segments .....

Ophiomusium anaelisae

4. Dorsal surface of disc almost entirely covered by centrodorsal and primary plates and radial shields, a single small interradial plate on edge of disc; three pairs of tentacle pores; one small appressed arm spine (sometimes two) .........

Ophiomisidium tommasii

4 '. Dorsal surface of disc with two interradial plates; four or five pairs of tentacle pores; two or three narrow arm spines, larger on basal segments, giving the animal a spiky appearance

5

5. Four pairs of tentacle pores; first lateral arm plate with two flattened spines (beneath the disc), second segment with three spines, and posterior segments with two spines...... Ophiomisidium pulchellum

5 '. Five pairs of tentacle pores; basal segments with three spines, posterior segments with two spines

Ophiomisidium speciosum

\section{Ophiolepididae \\ Ophiomusium acuferum Lyman, 1875}

Figs 1-5

Ophiomusium acuferum Lyman, 1875: 7; pl. I, figs 1-5; 1878: 108; 1883: 246 H.L.Clark, 1915: 329; 1941: 92; Tommasi, 1999.

Ophiomisidium pulchellum: (in Brazil) Tommasi, 1970: 76, figs 78-79; Borges et al., 2002: 23, figs 12-14; 2004: 157.

Redescription. Disc diameter: from 1.0 to $10.0 \mathrm{~mm}$. Disc. Covered by large scales, lightly swollen; pentagonal centre dorsal scale surrounded by the primary scales. Robust disc dorsal margin. Oval radial shields lightly elevated at the distal margin and separated by two or three scales, being the distal one rounded and elevated. An enlarged scale is present between each pair of radial shields in the interradii. This scale extends to the ventral surface and joins the oral shield (Figs 1 and 2). The ventral interradial region is covered by this large plate, the 

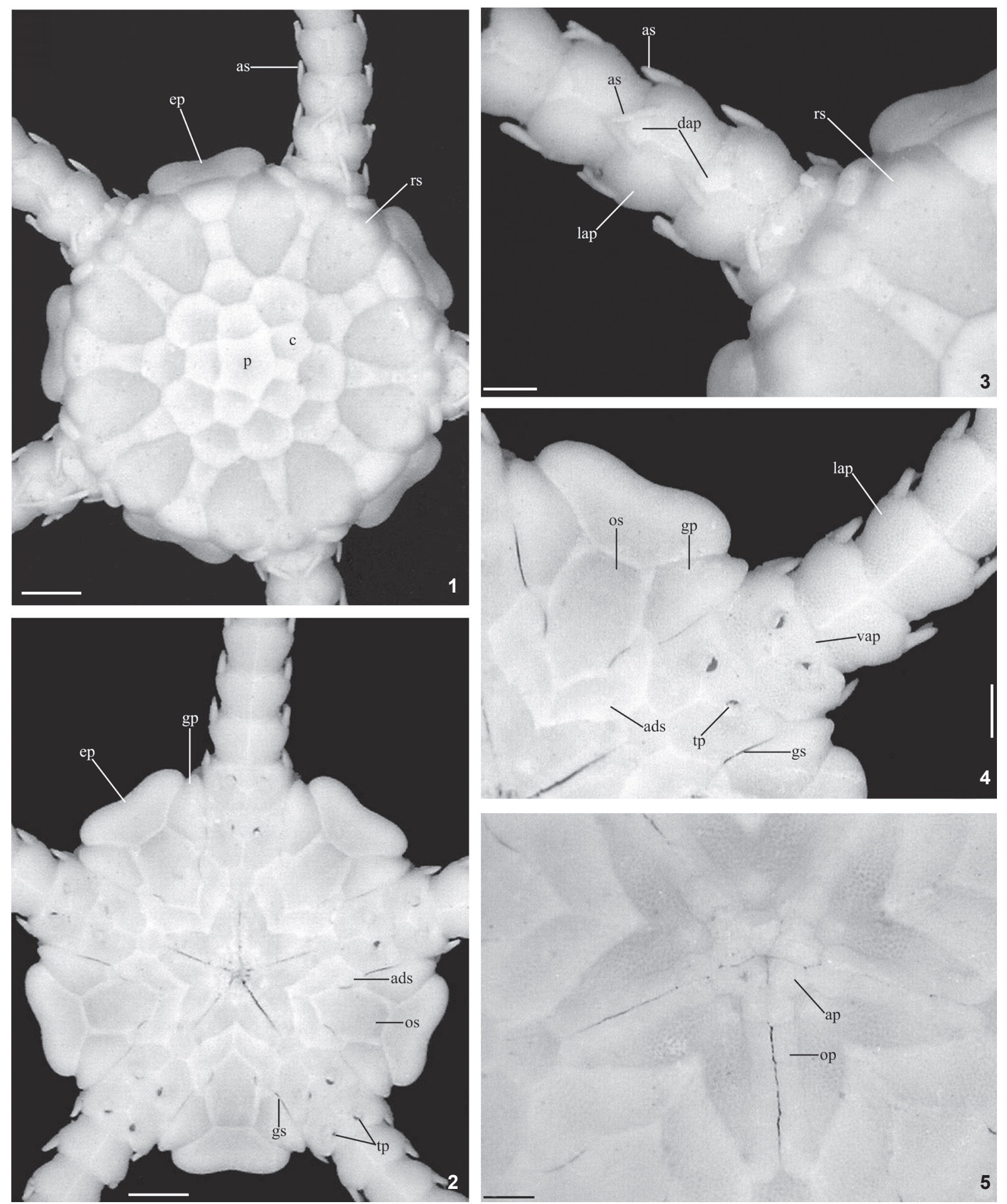

Figures 1-5. Ophiomusium acuferum: (1) dorsal view; (2) ventral view; (3) detail of the dorsal arm; (4) detail of the ventral region (shields and arm); (5) detail of the oral region. (ap) Apical papilla, (ads) adoral shield, (as) arm spine, (c) centrodorsal plate, (dap) dorsal arm plate, (ep) enlarged plate, (gp) genital plate, (gs) genital slip, (lap) lateral arm plate, (op) oral papilla, (os) oral shield, ( $p$ ) primary plate, (rs) radial shield, (tp) tentacle pore, (vap) ventral arm plate. Scale bars: 1-2 =1 mm, 3-4 = $0.5 \mathrm{~mm}, 5=0.3 \mathrm{~mm}$. 
well developed genital plates, and the oral and adoral shields (Figs 2 and 4). Well developed, pentagonal, proximally pointed oral shield; elongated adoral plates, proximally united and distally widened, partially separated from the oral shield by the elongated genital slit (Figs 2 and 4). Four to five oral papillae strongly united in each side of the jaw; an triangular apical papilla (Fig. 5). Arms. Length about three times the disc diameter. Triangular, small, dorsal arm plates (Fig. 3) present up to the 6th-7th arm segment; the first two ventral arm plates are very conspicuous, sub-pentagonal with lightly lateral recessed areas from the tentacle pores, posterior ones small and triangular present up to the $4^{\text {th }}-5^{\text {th }}$ arm segment (Fig. 4). Well developed lateral plates, united dorsal ventrally throughout almost the whole arm (Figs 3 and 4). Proximal lateral arm segments with three spines, one of which placed more dorsally and separated from the other two (Fig. 3). More distal arm segments with only two spines. Two pairs of tentacle pores in each arm, each pore with a circular tentacle scale (Figs 2 and 4).

Examined Material. 2.046 specimens observed: BrazIL, São

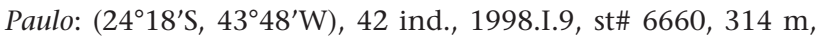

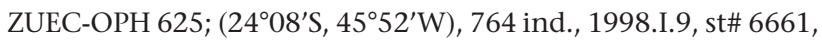
$150 \mathrm{~m}$, ZUEC-OPH 626; ( $\left.24^{\circ} 21^{\prime} \mathrm{S}, 4^{\circ} 10^{\prime} \mathrm{W}\right), 372$ ind., 1998.I.10,

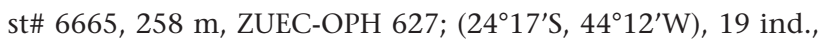
1998.I.10, st\# 6666, 163 m, ZUEC-OPH 628; ( $\left.24^{\circ} 17^{\prime} \mathrm{S}, 44^{\circ} 12^{\prime} \mathrm{W}\right)$, 1 ind., 1998.I.10, st\# 6666, 163 m, ZUEC-OPH 629; (25³7's, $\left.45^{\circ} 14^{\prime} \mathrm{W}\right), 145$ ind., 1998.I.13, st\# 6686, 380 m, ZUEC-OPH 630; $\left(24^{\circ} 31^{\prime} \mathrm{S}, 44^{\circ} 54^{\prime} \mathrm{W}\right), 3$ ind., 1998.I.11, st\# 6674, $122 \mathrm{~m}$, ZUEC-

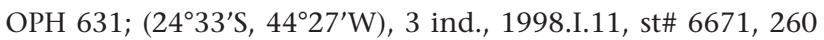
m, ZUEC-OPH 632; $\left(24^{\circ} 50^{\prime} \mathrm{S}, 44^{\circ} 45^{\prime} \mathrm{W}\right), 1$ ind., 1998.I.12, st\#

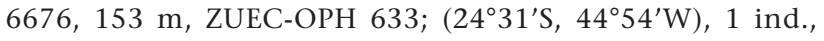
1998.I.11, st\# 6674, 122 m, ZUEC-OPH 634; ( $\left.24^{\circ} 41^{\prime} \mathrm{S}, 44^{\circ} 51^{\prime} \mathrm{W}\right)$, 1 ind., 1998.I.12, st\# 6677, 137 m, ZUEC-OPH 635; (25¹1's, $\left.44^{\circ} 57^{\prime} \mathrm{W}\right), 6$ ind., 1998.I.12, st\# 6681, $168 \mathrm{~m}$, ZUEC-OPH 636; $\left(26^{\circ} 28^{\prime} \mathrm{S}, 44^{\circ} 30^{\prime} \mathrm{W}\right), 42$ ind., 1998.I.11, st\# 6672, $165 \mathrm{~m}$, ZUECOPH 637; (24ำ $\left.18^{\prime} \mathrm{S}, 44^{\circ} 36^{\prime} \mathrm{W}\right), 25$ ind., 1998.I.11, st\# 6673, 133 m, ZUEC-OPH 638; (24 19'06"S, 44 40'06"W), 94 ind., 1987.VII,

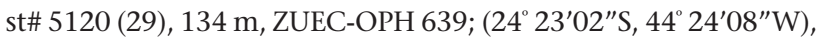
76 ind., 1987.VII, st\# 5192 (25), 180 m, ZUEC-OPH 640; (24 19'03"S, 44 13'02"W), 107 ind., 1987.VII, st\# 4931 (20), $188 \mathrm{~m}$,

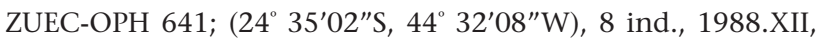

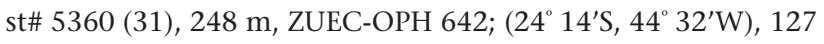
ind., 1987.VII, st\# 5148 (24), 134 m, ZUEC-OPH 643; (24 36'04"S, $\left.44^{\circ} 33^{\prime} 03^{\prime \prime} \mathrm{W}\right), 44$ ind., 1987.VII, st\# 5191 (30), 184 m, ZUECOPH 644; (24 42’05"S, $\left.44^{\circ} 30^{\prime} \mathrm{W}\right), 15$ ind., 1988.XII, st\# 7361 (32), $320 \mathrm{~m}$, ZUEC-OPH 645; (24 $\left.25^{\prime} \mathrm{S}, 44^{\circ} 16^{\prime} 05^{\prime \prime} \mathrm{W}\right), 8$ ind.,

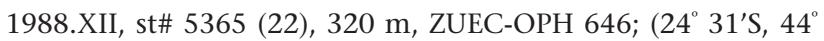
28'W), 35 ind., 1988.XII, st\# 5368 (26), 250 m, ZUEC-OPH 647;

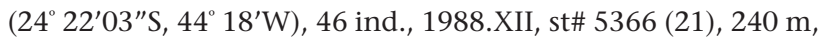
ZUEC-OPH 648; ( $24^{\circ} 22^{\prime}$ 'S, $\left.44^{\circ} 54^{\prime} \mathrm{W}\right), 4$ ind., 1986.VII.29, st\# 4954 (18 I), $101 \mathrm{~m}, \mathrm{ZUEC}-\mathrm{OPH} 649$; ( $\left.23^{\circ} 45^{\prime} \mathrm{S}, 45^{\circ} 00^{\prime} \mathrm{W}\right), 5$ ind., 1986.IV.20, st\# 5170 (19), 46 m, ZUEC-OPH 650; (2313'S, $\left.44^{\circ} 45^{\prime} \mathrm{W}\right), 1$ ind., 1986.VII.27, st\# 4951 (15 I), 117 m, ZUEC-

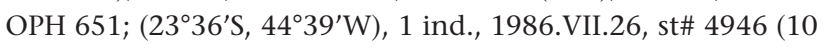

I), 50 m, ZUEC-OPH 652; ( $\left.24^{\circ} 08^{\prime} \mathrm{S}, 45^{\circ} 52^{\prime} \mathrm{W}\right), 13$ ind., 1998.I.09, st\# 6661, 147 m, ZUEC-OPH 653; Rio de Janeiro: (23³6.511S, $\left.42^{\circ} 01.71^{\prime} \mathrm{W}\right), 16$ ind., 1987.V.01, MD55, st\# 62 CB103, $200 \mathrm{~m}$, MNHN IE 2007-3; Espírito Santo: (1859.37'S, 37050.05’W), 2 ind., 1987.V.27, MD55, st\# 42 DC75, 315m, MNHN IE 2007-1; (19³4.21'S, 38 $\left.55.01^{\prime} \mathrm{W}\right), 19$ ind., 1987.V.30, MD55, st\# 53 CB92, $285 \mathrm{~m}, \mathrm{MNHN}$ IE 2007-2.

Occurrence. Espírito Santo, Rio de Janeiro and São Paulo (southeastern Brazil).

Geographical and Bathymetric Distribution. West Atlantic: Florida, Gulf of Mexico, Central America and Brazil. Indian Ocean: west of India. From 70 to 600 m depth (Lyman 1875, 1878,1883 , H.L.Clark 1915, 1941). The study samples here were taken from 46 to $380 \mathrm{~m}$.

\section{Ophiuridae \\ Ophiomisidium pulchellum (C.W. Thomson, 1877)} Figs 6-10

Ophiomusium pulchellum: C.W. Thomson, 1877: 67; Lyman, 1878: 118; 1882: 96; Koehler, 1907: 266.

Ophiomisidium pulchellum: Koehler, 1914: 32; A.M. Clark \& Courtman-Stock, 1976: 190; Paterson, 1985: 141.

Redescription. Disc diameter: up to $5.0 \mathrm{~mm}$. Disc. Lightly elevated, covered by a few swollen scales. Granular microstructure. Pentagonal centrodorsal scale surrounded by five primary sub-pentagonal scales, which have three straight proximal sides and a round distal margin. Oval radial shields nearly united throughout their lengths, only separated proximally by one of the primary scales, and at the distal border by a small triangular scale that touches the first dorsal arm plate. Two scales between each pair of radial shields, the proximal one rectangular and the distal one trapezoidal, slightly rounded (Figs 6 and 8 ). Ventral interradii less developed, each covered by an interradial sub-trapezoidal elongated plate, that elongates from the edge of the oral shield to the margin of the disc, surrounded by the genital plates, oral and adoral shields (Figs 7 and 9). This central scale is more pointed at the proximal edge and enlarged distally (Fig. 9). The genital plates may touch each other near the oral shield at one or more jaws in a single individual. Oral shields with round borders, diamond-shaped, almost as long as wide. Well developed adorals, proximally united, shortened at the posterior edge, and touching the first lateral arm plate (Figs 9 and 10). Two lateral narrow oral papillae strongly united. Distal one largest occupying more than half of the jaw's marginal length. Proximal one smallest and sub-elliptical. One triangular apical papillae (Fig. 10). Bursal slit very small opening between the genital plate and the first lateral arm plate (Fig. 9). Arms. Arm length once or twice the size of the disc diameter (Fig. 7). First dorsal arm plate twice as large than long with the proximal border touching the triangular plate, which separates the radial shields; round distal margin. Losangular small posterior dorsal arm plates (Fig. 8), 


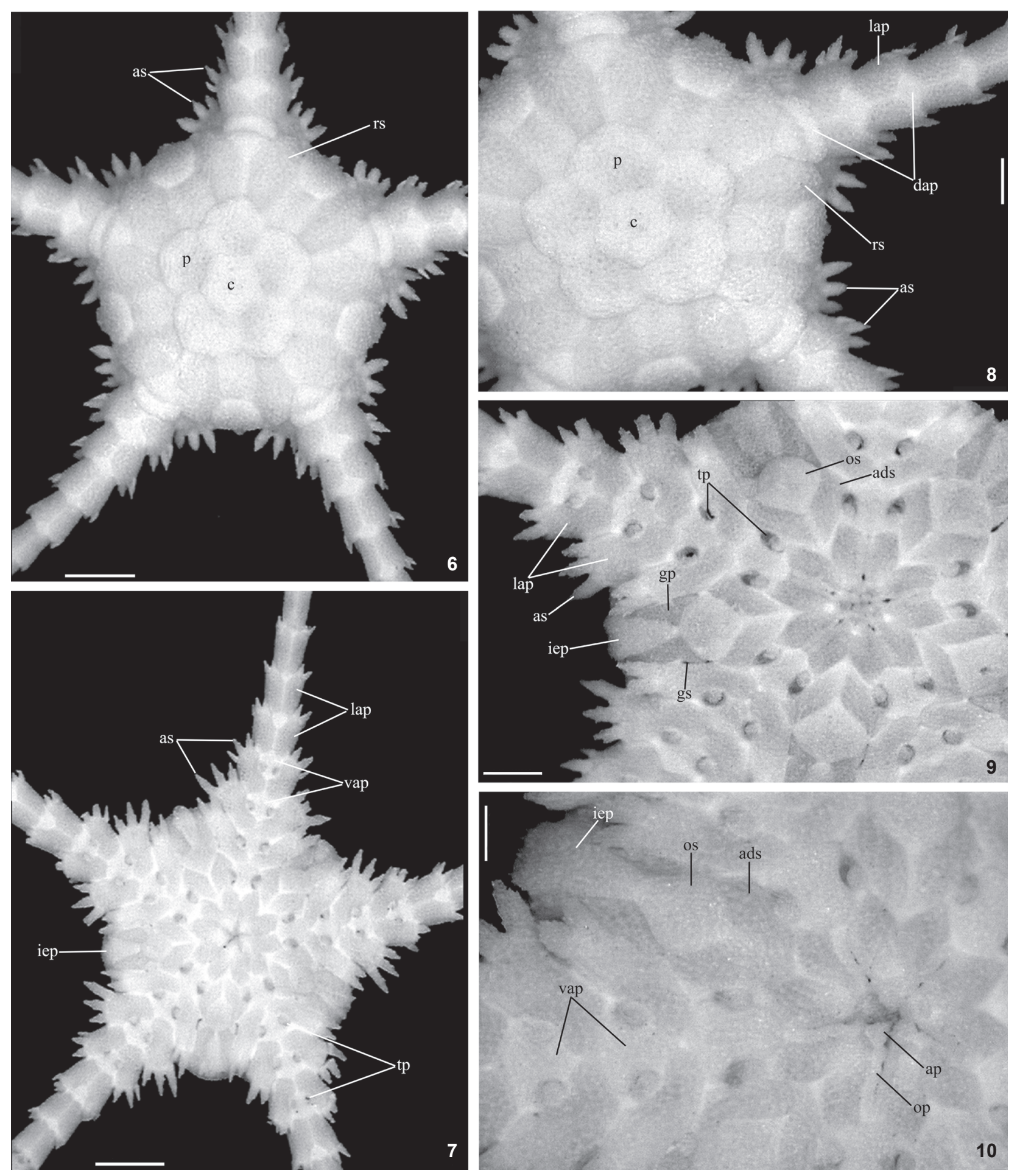

Figures 6-10. Ophiomisidium pulchellum: (6) dorsal view; (7) ventral view; (8) detail of the disk and dorsal arm; (9) detail of the ventral region (shields and arm); (10) detail of the oral region. (ap) Apical papilla, (ads) adoral shield, (as) arm spine, (c) centrodorsal plate, (dap) dorsal arm plate, (gp) genital plate, (gs) genital slip, (iep) interradial elongated plate, (lap) lateral arm plate, (op) oral papilla, (os) oral shield, $(p)$ primary plate, $(r s)$ radial shield, $(t p)$ tentacle pore, (vap) ventral arm plate. Scale bars: 6-7 = $1 \mathrm{~mm}, 8-9=0.5 \mathrm{~mm}, 10=0.3 \mathrm{~mm}$. 
which diminish in size towards the extremity of the arm, but present only till the seventh or eighth segment. Four first subhexagonal ventral arm plates with their proximal and distal margins lightly pointed with concave lateral edges that accommodate the tentacle pores (Figs 9 and 10). Triangular posterior ventral plates (Fig. 9), which reduce their size towards the extremity of the arm. Well developed lateral arm plates that joined dorsally and ventrally (Figs 7-9). Four pairs of tentacle pores at the basal arm segments covered by a circular tentacle scale (Figs 7 and 9). Irregularly shaped, slightly flattened, and rugose spines at the first segments of the arm (Figs 6-9). First lateral arm plate with two flattened spines under the disc. The second arm segment with three spines, the posterior ones with two spines, and the following segments have spines that rapidly diminish in size throughout the arm (Fig. 9).

Examined Material. 284 specimens observed: BrazIL, Rio de Janeiro: $\left(22^{\circ} 11.749^{\prime} \mathrm{S}, 39^{\circ} 51.740^{\prime} \mathrm{W}\right), 8$ ind., 2003.VIII.22, st\# BCN 10, 1100 m, DZ/IB/UFRJ EO 157; (22 $24.419^{\prime} \mathrm{S}, 39^{\circ} 55$. $\left.556^{\prime} \mathrm{W}\right), 27$ ind., 2003.VIII.28, st\# BCS 4-2, 1105m, DZ/IB/UFRJ EO $158 ;\left(22^{\circ} 16.07^{\prime} \mathrm{S}, 39^{\circ} 51.556^{\prime} \mathrm{W}\right), 1$ ind., 2003 .VIII. 24 , st\# BCN 17-2, 1300 m, DZ/IB/UFRJ EO 159; (2153.524'S, 3951.163’W), 27 ind., 2003.VIII.20, st\# BCN 13-2, 1073 m, DZ/IB/UFRJ EO 161 ; (21 $\left.{ }^{\circ} 531.41^{\prime} \mathrm{S}, 39^{\circ} 51.431^{\prime} \mathrm{W}\right), 2$ ind., 2003.VIII.20, st\# BCN 13-1, 1064 m, DZ/IB/UFRJ EO 163; (22 $\left.{ }^{\circ} 16.304^{\prime} \mathrm{S}, 39^{\circ} 53.360^{\prime} \mathrm{W}\right)$, 3 ind., 2003.VIII.22, st\# BCN 16, 1059 m, DZ/IB/UFRJ EO 165; $\left(23^{\circ} 10.72^{\prime} \mathrm{S}, 42^{\circ} 10.73^{\prime} \mathrm{W}\right), 175$ ind., 1987.VI.02, MD55, st\# 65 CB106, 825 m, MNHN IE 2007-5; (2400.32's, 42 $\left.14.07^{\prime} \mathrm{W}\right), 40$ ind., 1987.VI.02, MD55, st\# 66 CB107, 1010 m, MNHN IE 20076; Espírito Santo: $\left(19^{\circ} 00.72^{\prime} \mathrm{S}, 37^{\circ} 48.33^{\prime} \mathrm{W}\right), 1$ ind., 1987.V.27, MD55, st\# 44 CB78, 1200 m, MNHN IE 2007-4.

Occurrence. Espírito Santo and Rio de Janeiro (southeast Brazil).

Geographical and Bathymetric Distribution. Eastern Atlantic: from the Bay of Biscay south to off the Cape of Good Hope. West Atlantic: off South Carolina and Pernambuco and Rio de Janeiro (Brazil). From 70 to 3063 m depth (Lyman 1878, 1882, Koehler 1907, 1914, A.M. Clark \& Courtman-Stock 1976, Paterson 1985). The study samples here were taken from 825 to $1300 \mathrm{~m}$.

\section{DISCUSSION}

Over the years since Tommasi (1970), several specimens of $O$. acuferum sampled from Brazilian waters have been identified as $O$. pulchellum. This confusion was probably generated by a description and a photograph supposedly representing $O$. pulchellum in the widely used Brazilian Ophiuroidea key by Tommasi (1970), but that actually has an account and shows a picture of $O$. acuferum. A detailed re-analysis of the supposedly O. pulchellum samples examined in Borges et al. $(2002,2004)$ and other material including specimens of both species sampled through the MD55/Brazil and 'Campos Basin Deep Sea Environmental Project/PETROBRAS' provided evidence for this misunderstanding, and aimed at clarifying this issue.
The species identified as O. pulchellum shows characteristics that resemble Ophiomusium, and more specifically $O$. acuferum. This latter species was first described by LYMAN (1875) from samples originated in Florida and Barbados from 70 to $180 \mathrm{~m}$ depth. Tommasi (1999) in his 'Recent and Fossil Echinoderm Record for Brazil' includes O. acuferum, but does not make any reference to its origin.

Although Koenler (1914) had mentioned an intimate relationship between Ophiomisidium and Ophiomusium, the latter can be distinguished by external features such as the second tentacle oral pore opening within the oral slit, the restricted number of tentacle pores ( 2 pairs in each arm), biggest adult size, highest number of dorsal plates on disc.

A comparative analysis of the material examined here and the original description of O. acuferum has shown that most specimens studied here and those previously recorded in Brazil belong in fact to Ophiomusium. Features such as the well developed interradial space, partially filled with the large oral shield; also, the structure, length and the way the arms are connected to the disc differ considerably, as in O. pulchellum a small ventral interradial space is observed as well as a considerable enlargement of the first lateral arm plates and an arm length of around two times the size of the disc diameter. Ophiomusium acuferum has similar size lateral arm plates throughout the whole arm, and this is several times bigger than the disc diameter. One unmistakable feature that distinguishes both genera is the number of the tentacle pore pairs in each arm. Ophiomisidium pulchellum has four pairs and O. acuferum has only two pairs, which is common for this latter genus.

When comparing species of Ophiomusium, LyMan (1878) approaches $O$. acuferum and $O$. lütkeni, but distinguishes both species only by the presence of enlarged dorsal plates in the first one. Tommasi \& Abreu (1974) described another Ophiomusium species for Brazil, O. anaelisae. Also, Borges \& Amaral (2007) registered O. eburneum Lyman, 1869 off the Brazilian southeastern region. This latter species differs from O. acuferum in characteristics such as: the adults' size; number and arrangement of dorsal and ventral disc plates; size, location, and number of the arm spines. The occurrence of $O$. acuferum in Brazil is not mentioned in any other work except in the catalogue by TomMAsI (1999), where an ophiuroid taxonomic key is presented with no image associated with it, but not much detail is given on this particular species, and the conundrum continued.

Taking into account the evidence provided here, the species O. pulchellum mencioned in TOMMASI (1970) and Borges et al. $(2002,2004)$ must be considered as O. acuferum, and the detailed description of $O$. pulchellum provided here should be taken into consideration for the identification of this species.

\section{ACKNOWLEDGEMENTS}

This work was supported by the state of São Paulo Research Foundation (FAPESP), as part of the Proc. 02/04298-0. 
Our thanks to the Conselho Nacional de Desenvolvimento Científico e Tecnológico, the Ministério do Meio Ambiente, dos Recursos Hídricos e da Amazônia Legal, and the Comissão Interministerial para os Recursos do Mar for their support to the 'REVIZEE' Programme, and also the Instituto Oceanográfico, Universidade de São Paulo for its financial support to the 'Integrado' Programme. We thank Ana M.G. Monteiro for her valuable assistance, and Ana M.S.P. Vanin (Integrado Programme Coordinator) for supplying some of the ophiuroid samples analysed here. We are grateful to Gordon Paterson and Nadia Ameziane for their useful discussions and allowing us access to the collections from the London 'Natural History Museum' and the Paris 'Muséum national d'Histoire naturelle' respectively.

\section{LITERATURE CITED}

Amaral, A.C.Z.; P.C. Lana; F.C. Fernandes \& J.C. Coimbra. 2004. Caracterização do ambiente e da macrofauna bentônica, p. 1146. In: A.C.Z. Amaral \& C.L.B. Rossi-Wongtschowski (Eds). Biodiversidade bentônica da região Sudeste-Sul do Brasil, Plataforma externa e talude superior. São Paulo, Instituto Oceanográfico, USP, Série Documentos Revizee: Score Sul, 216p.

Borges, M. \& A.C.Z. Amaral. 2007. Ophiuroidea (Echinodermata): quatro novas ocorrências para o Brasil. Revista Brasileira de Zoologia 24 (4): 855-864.

Borges, M.; A.M.G. Monteiro \& A.C.Z. Amaral. 2002. Taxonomy of Ophiuroidea (Echinodermata) from the continental shelf and slope of the southern and southeastern Brazilian coast. Biota Neotropica 2 (2): 1-69.

Borges, M.; A.M.G. Monteiro \& A.C.Z. Amaral. 2004. Classe Ophiuroidea, p: 156-160. In: A.C.Z. Amaral \& C.L.B. RossiWongtschowsKi (Eds). Biodiversidade Bentônica da Região Sudeste-Sul do Brasil, plataforma externa e talude superior. São Paulo, Instituto Oceanográfico, USP, Série Documentos Revizee: Score Sul, 216p.

ClaRk, A.M. \& J. COURTMANSTOCK. 1976. The echinoderms of southern Africa. London, British Museum (Natural History), 277p.

Clark, H.L. 1915. Catalogue of recent ophiurans: based on the collection of the Museum of Comparative Zoology. Memoirs of the Museum of Comparative Zoology 25 (4): 165-376.

Clark, H.L. 1941. Reports on the scientific results of the Atlantis Expeditions to the West Indies. The Echinoderms (other than holothurians). Memorias de la Sociedad Cubana de Historia Natural "Felipe Poey" 15: 69-107.

Guille, A. \& J.M. Ramos. 1987. Les rapports des campagnes à la mer TAAF MD55/Brésil à bord du Marion Dufresne 6 mai-2 juin 1987. La Riche, Technical Report 87-03, Instaprint, 198p.
Koenler, R. 1907. Ophiures. Expeditions Scientifiques du Travailleur et du Talisman 8: 245-311.

KoeHLer, R. 1914. A contribution to the study of Ophiurans of the United States National Museum. Bulletin of the United States National Museum 84: 1-173.

Lyman, T. 1869. Preliminary report on the Ophiuridae and Astrophytidae dredged in deep water between Cuba and the Florida Reef by L.F. de Pourtales. Bulletin of the Museum of Comparative Zoology (10): 309-354.

Lyman, T. 1875. Zoological results of the Hassler Expedition. II. Ophiuridae and Astrophytidae. Illustrated Catalogue of the Museum of Comparative Zoology (8): 1-34.

Lyman, T. 1878. Ophiuridae and Astrophytidae of the exploring voyage of the HMS "Challenger", Part I. Bulletin of the Museum of Comparative Zoology 5 (7): 65-168.

Lyman, T. 1882. Report on the Ophiuroidea. Report of the Scientific Results of the voyage of H.M.S. Challenger 187376. Zoology 5 (1): 1-386.

Lyman, T. 1883. Report on the results of dredging, under the supervision of Alexander Agassiz in the Caribbean Sea in 1878-79 and along the Atlantic coast of the United States during the summer of 1880 , by the US Coast Survey Steamer Blake. Report on the Ophiuroidea. Bulletin of the Museum of Comparative Zoology 10 (6): 227-287.

Paterson, G.L.J. 1985. The deep-sea Ophiuroidea of the North Atlantic Ocean. Bulletin of the British Museum (Natural History) Zoology 49 (1): 1-162.

Pires-Vanin, A.M.S. 1993. A macrofauna bêntica da plataforma continental ao largo de Ubatuba, São Paulo, Brasil. Publicações Especiais do Instituto Oceanográfico São Paulo (10): 137-158.

Tavares, M. 1999. The cruise of the Marion Dufresne off the Brazilian coast: account of the scientific results and list of stations. Zoosystema 21 (4): 597-605.

Thomson, C.W. 1877. The voyage of the Challenger. The Atlantic. A preliminar account of the general results of the exploring Voyage of H.M.S. Challenger 1: 1-424.

TommASI, L.R. 1970. Os ofiuróides recentes do Brasil e de regiões vizinhas. Contribuições Avulsas do Instituto Oceanográfico, Universidade de São Paulo, Série Oceanografia Biológica (20): 1-146.

Tommasi, L.R. 1999. Echinodermata Recentes e Fósseis do Brasil. Available online at: http://www.bdt.org.br/zoologia/ echinodermata [Accessed: 12. IV. 2003]

Tommasi, L.R. \& J. Abreu. 1974. Equinodermes do Brasil. IV. Sobre seis espécies novas de Ophiuroidea da região ao largo da Ilha Grande (RJ). Boletim do Instituto Ooceanográfico, Universidade de São Paulo 23: 17-32.

Submitted: 06.IV.2010; Accepted: 13.XI.2010.

Editorial responsibility: Rosana M. da Rocha 